\title{
Permanent Section
}

National Cancer Institute

\section{Source}

National Cancer Institute. Permanent Section. NCI Thesaurus. Code C67463.

A thin slice of fixative-preserved tissue mounted on a slide for microscopic examination. 